MARIUSZ RUSZEL

Politechnika Rzeszowska

\title{
Znaczenie gazociągu Nord Stream 2 dla polityki energetycznej Republiki Federalnej Niemiec
}

\section{The importance of the Nord Stream 2 gas pipeline for the energy policy of the Federal Republic of Germany}

\begin{abstract}
The aim of this article is to analyse the strategic role of the Nord Stream 2 pipeline for the German energy policy. The author assumes a geo-economic approach. He hypothesises that Nord Stream 2 will support Germany's position as a distribution centre of natural gas for the European Union. Therefore, the following research hypotheses are considered. Firstly, the energy cooperation between Germany and the Russian Federation strengthens German's political position in Central and Eastern Europe. Secondly, the development of energy infrastructure serves a fundamental role in building the political position of Germany. Thirdly, the creation of the gas distribution centre in Germany will weaken the position of Ukraine and Slovakia as transit states.
\end{abstract}

Keywords: Nord Stream 2, energy security, energy policy, Federal Republic of Germany

Słowa kluczowe: Nord Stream 2, bezpieczeństwo energetyczne, polityka energetyczna, Republika Federalna Niemiec

\section{Wprowadzenie}

Republika Federalna Niemiec (RFN) jest położonym w centrum Europy państwem, które odgrywa kluczową rolę w zakresie kształtowania strategicznych celów polityki energetycznej Unii Europejskiej (UE) ${ }^{1}$. Niemiecka strategia energetyczna współkształtowana jest przez czynniki krajowe oraz otoczenie

1 Traktat z Lizbony wprowadził Tytuł XXI „Energetyka” (art. 194), w którym wskazano cele polityki energetycznej UE: „a) zapewnienie funkcjonowania rynku energii; b) zapewnienie bezpieczeństwa dostaw energii w UE; c) wspieranie efektywności energetycznej; d) oszczędzanie energii; e) rozwój odnawialnych źródeł energii (OZE); f) wspieranie wzajemnych połączeń pomiędzy sieciami energii”. Zob. Traktat o funkcjonowaniu Unii Europejskiej, Dz. Urz. UE C 326/47, s. 134-135. 
międzynarodowe. Teoretyczno-metodologiczna analiza przeprowadzona przez Erharda Cziomera pozwala wnioskować, że kluczową rolę odgrywają te pierwsze, gdyż bezpośrednio odpowiadają za kształtowanie celów polityki zagranicznej państwa ${ }^{2}$. W ujęciu teoretycznym podkreśla się, że polityka zagraniczna jest aktywnością związaną z polityką wewnętrzną, która z kolei odzwierciedla interesy grup wewnątrzpaństwowych ${ }^{3}$. W odniesieniu do RFN trzeba pamiętać, że oprócz rządu federalnego (niem. Bundesregierung) podmiotami tamtejszej polityki energetycznej są landy (niem. Bundesländer), które również mają swoje interesy w tym obszarze ${ }^{4}$. Specyfiką niemieckiej polityki energetycznej jest umiejętność wykorzystywania do budowy pozycji międzynarodowej czynników wewnętrznych, a także szans wynikających z położenia geograficznego i sojuszy politycznych ${ }^{5}$. Szczególnie istotną rolę odgrywa na tym polu niemiecki biznes, silnie zorientowany na eksport swoich produktów i usług. Oddziałuje on na ośrodki polityczne państwa, aby prowadziło politykę zagraniczną ułatwiającą mu sprzedaż na chłonne rynki. Wpisuje się to w stwierdzenie Stephena F. Szabo, który podkreślił, że okres odbudowy Niemiec po drugiej wojnie światowej miał na celu rozbudowę gospodarki oraz konkurencyjności przemysłu ${ }^{6}$. Taki model rozwoju państwa prowadził do stworzenia niemieckiej potęgi cywilnej (ang. civilian power) ${ }^{7}$, która najlepiej rozwija się w warunkach międzynarodowej współpracy opartej na integracji europejskiej ${ }^{8}$, ale również selektywnym multilateralizmie ${ }^{9}$ i sojuszach energetycznych ${ }^{10}$. W literaturze przedmiotu podkreśla się, że niemiecki model gospodarki (potęgi gospodarczej - ang. trade power, geo-economic

2 E. Cziomer, Polityka zagraniczna Niemiec $w$ dobie wyzwań globalizacji, bezpieczeństwa międzynarodowego oraz integracji europejskiej po 2005 roku, Dom Wydawniczy ELIPSA, Warszawa-Kraków 2010, s. 24.

3 Leksykon politologii, red. A. Antoszewski, R. Herbut, Atla 2, Wrocław 2000, s. 430-431.

4 F. Illing, Energiepolitik in Deutschland. Die energiepolitischen Maßnahmen der Bundesregierung 1949-2015, Nomos, Baden-Baden 2016, s. 32.

5 E. Cziomer, Polityka..., s. 24.

6 S.F. Szabo, Germany, Russia and the rise of geo-economics, Bloomsbury Publishing, London-New Dehli-New York-Sydney 2014, s. 5.

7 Germany as civilian power? The foreign policy of the Berlin Republic, ed. S. Harnisch, H. Maull, Manchester University Press, Manchester-New York 2001.

8 Schwerpunkte deutscher Außenpolitik, „Deutsche Vertretungen in der Türkei” [online, dostęp: 20.01.2017], dostępny w internecie: <https://tuerkei.diplo.de/tr-de/themen/ politik/-/1670126>.

9 H. Kundnani, Germany as a geo-economic power, „The Washington Quarterly” 2011, vol. 34, issue 3, s. 31-45.

10 R. Ulatowski, Analiza porównawcza polityki energetycznej importerów i eksporterów surowców energetycznych na przykładzie Niemiec i Arabii Saudyjskiej. Perspektywa geoekonomiczna, Wydawnictwo Naukowe Scholar, Warszawa 2016. 
power) osiąga najlepsze rezultaty w warunkach stabilności i pokoju światowego, gdyż istnieją wówczas optymalne możliwości eksportu technologii, standardów, norm, towarów i usług, jak również związanych z nimi modeli i rozwiązań, które mają zastosowanie w przemyśle ${ }^{11}$.

Strategicznym celem polityki energetycznej RFN jest zapewnienie bezpieczeństwa energetycznego państwa, tzn. ciągłości dostaw energii w akceptowalnej cenie, a przez to stworzenie warunków do funkcjonowania konkurencyjnej gospodarki i przemysłu z możliwie najmniejszym obciążeniem dla środowiska naturalnego ${ }^{12}$. Niemcy realizują proces modernizacji energetycznej (Energiewende), której celem jest zastąpienie energetyki wysokoemisyjnej energetyką odnawialną. W rządowej strategii Climate Action Plan 2050 sformułowane zostały następujące cele niemieckiej polityki energetycznej:

a) Udział energii elektrycznej wytworzonej z energii słonecznej, wiatrowej itp. w finalnym zużyciu energii brutto powinien wzrosnąć z 11\% w $2010 \mathrm{r}$. do $60 \%$ w $2050 \mathrm{r}$.

b) Udział odnawialnych źródeł energii w produkcji energii elektrycznej powinien wynieść co najmniej $35 \%$ do 2020 r., a ponad $80 \%$ do 2050 r.

c) Emisja gazów cieplarnianych powinna zmniejszyć się względem roku 1990 o $40 \%$ do 2020 i przynajmniej o $80 \%$ do 2050 .

d) Zużycie energii pierwotnej obniży się do 2020 r. o 20\%, a do 2050 r. o $50 \%$ w stosunku do $2008 \mathrm{r}$.

e) Osiągnięty zostanie wzrost efektywności energetycznej o średnio $2,1 \%$ w stosunku do finalnego zużycia energii w skali roku.

f) Zużycie energii elektrycznej brutto powinno być zmniejszone do 2050 r. o $25 \%$ w odniesieniu do 2008 r.

g) Zapotrzebowanie na ciepło budynków powinno być zmniejszone o $20 \%$ do $2020 \mathrm{r}$.

h) Finalne zużycie energii w sektorze transportu powinno być obniżone o $10 \%$ do 2020 r. oraz $40 \%$ do 2050 r. w odniesieniu do 2005 r. $^{13}$

Dostrzega się, że istotną rolę w realizacji założeń strategicznych odgrywać mają energetyka odnawialna oraz gaz ziemny. Niemcy są państwem, które nie dysponuje wystarczającą ilością własnych surowców energetycznych, jak

11 H. Kundnani, Germany..., s. 31-45.

12 M. Ruszel, Strategia polityki energetycznej Republiki Federalnej Niemiec, „Sprawy Międzynarodowe" 2017, t. 70, nr 2, s. 82-96.

13 Energiewende im Überblick, „Die Bundesregierung” [online, dostęp: 4.07.2017], dostępny w internecie: <https://www.bundesregierung.de/breg-de/themen/energiewende/ energiewende-im-ueberblick-229564>. 
ropa naftowa, gaz ziemny oraz uran, dlatego muszą je importować ${ }^{14}$. W $2017 \mathrm{r}$. krajowe wydobycie gazu ziemnego wystarczyło im do pokrycia 5\% zapotrzebowania na ten surowiec, podczas gdy import (głównie z Federacji Rosyjskiej, Norwegii i Holandii) stanowił 95\%.

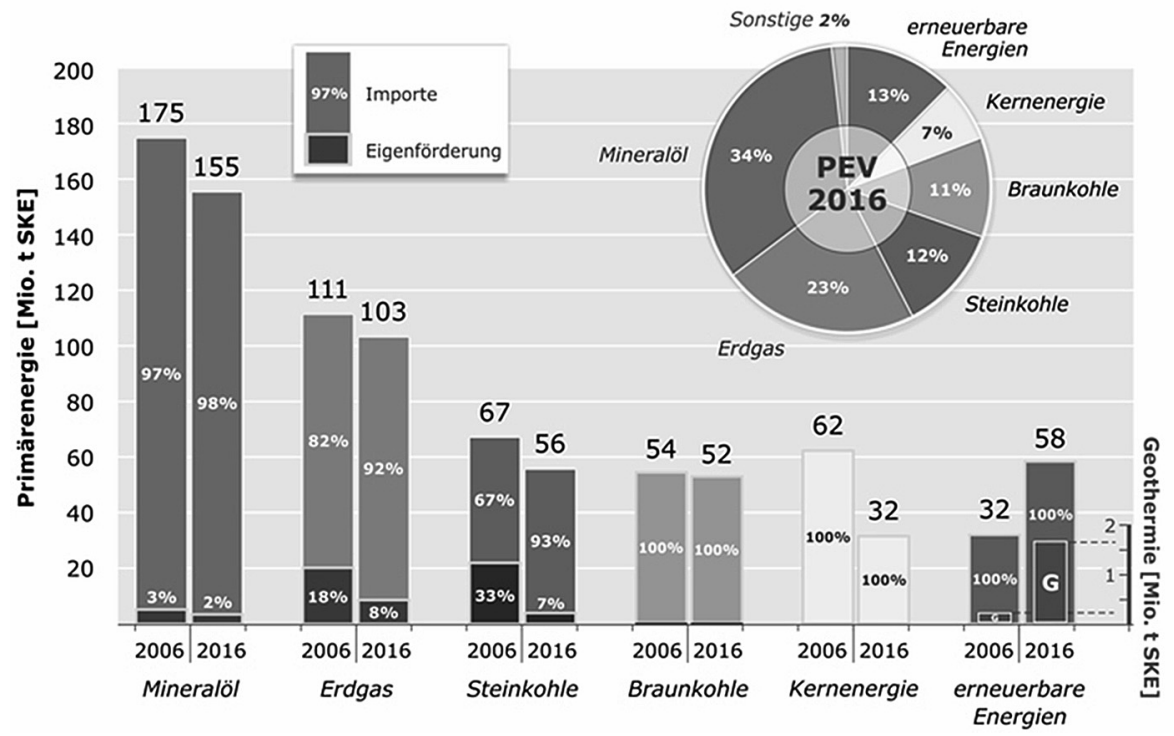

Diagram 1. Zależność importowa oraz struktura bilansu energii pierwotnej w Republice Federalnej Niemiec w 2006 oraz 2016 r.

Źródło: Importabhängigkeit und Selbstversorgungsgrad Deutschlands bei einzelnen

Primärenergierohstoffen in den Jahren 2006 und 2016, „BGR” [online, dostęp:

24.11.2018], dostępny w internecie: <https:/www.bgr.bund.de/DE/Themen/Energie/Bilder/

Energiestudie2017/ene_importabhaenigkeit_2016_g.html?nn=1542226>

Powszechnie przyjmuje się, że przewagę konkurencyjną mają państwa zasobne w surowce energetyczne, a sam dostęp do nich jest podłożem wojen i konfliktów ${ }^{15}$. Jednakże odpowiednio rozbudowana infrastruktura energetyczna oraz silne relacje energetyczne $\mathrm{z}$ państwami zasobnymi w te surowce mogą sprzyjać budowie pozycji tranzytowej, a docelowo wzmocnić polityczne znaczenie państwa ${ }^{16}$. W $2017 \mathrm{r}$. import gazu ziemnego do Niemiec

14 M. Ruszel, Strategic goals of energy security policy of the Federal Republic of Germany, „Politeja” 2015, nr 5 (50), s. 113-130.

15 M. Klare, Resource wars. The new landscape of global conflict, Metropolitan Books, New York 2001, s. 27-137.

16 B. Molo, Polityka bezpieczeństwa energetycznego Niemiec w XXI wieku, Oficyna Wydawnicza Krakowskiej Akademii im. Frycza Modrzewskiego, Kraków 2013. 
był o kilkadziesiąt miliardów metrów sześciennych większy niż krajowe zapotrzebowanie, co umożliwiło reeksport tego surowca.

Celem niniejszego artykułu jest odpowiedź na pytanie, w jakim celu Republika Federalna Niemiec uczestniczy w realizacji projektu gazociągu Nord Stream 2. Skoncentrowano się tu na podmiocie państwowym, a przedmiotem rozważań jest polityka energetyczna. Autor postawił tezę, że realizacja tego projektu przyczyni się do stworzenia w RFN centrum dystrybucji gazu ziemnego dla Europy Środkowo-Wschodniej. Podporządkowano jej następujące hipotezy badawcze. Po pierwsze, współpraca energetyczna pomiędzy Niemcami a Federacją Rosyjską wzmacnia niemiecką pozycję polityczną w Europie Środkowo-Wschodniej. Po drugie, fundamentem budowy pozycji politycznej RFN jest rozwinięta infrastruktura energetyczna. Po trzecie, budowie centrum dystrybucji gazu ziemnego w Niemczech sprzyjać będzie osłabienie pozycji tranzytowej Ukrainy oraz Słowacji.

\section{Strategiczne znaczenie Nord Stream 2}

\section{Z perspektywy strategicznej gazociąg Nord Stream 2 przyczynia się do większej kontroli Federacji Rosyjskiej i RFN nad szlakami przesyło-} wymi gazu ziemnego między oboma państwami. Rosyjski gaz zwiększa stabilność systemu energetycznego Niemiec, dlatego postrzegają one kolejne nitki Gazociągu Północnego jako czynnik bezpieczeństwa w tym sektorze. Istotną rolę w bilansie energetycznym RFN odgrywają niestabilne źródła energii odnawialnej, a w sytuacji dyskusji nad przyszłością energetyki węglowej oraz jądrowej kluczowe znaczenie będzie miał gaz. W związku z tym Berlin dąży do zwiększania bezpieczeństwa dostaw błękitnego paliwa poprzez eliminację ryzyka politycznego wynikającego z tranzytu przez państwa trzecie. Budowa gazociągu Nord Stream 2 przyczyni się przede wszystkim do ograniczenia roli Ukrainy i Słowacji, przez które przepływa znaczna ilość rosyjskiego gazu ziemnego do UE, a w konsekwencji zmniejszenia ich bezpieczeństwa tranzytowego i obniżenia wpływów budżetowych z tego tytułu. Spowoduje to polityczne i ekonomiczne osłabienie tych państw, a w dłuższej perspektywie podważy zasadność utrzymywania przebiegających przez nie magistrali gazociągów przesyłowych. Ukraina utraciłaby więc ważny argument polityczny w relacjach dwustronnych z Rosją, w związku z czym mogłaby się stać obiektem presji politycznej ze strony Kremla. Dotychczasowe relacje tych państw cechowała współzależność polityczna, a po wybudowaniu Nord Stream 2 staną się one asymetryczne na korzyść Rosji. Podobnie może 
wyglądać sytuacja Słowacji, która stanie się bardziej podatna na wpływ polityczny ze strony Federacji Rosyjskiej. Wraz z utratą roli tranzytowej Ukraina i Słowacja będą zwiększały swą zależność od dostaw gazu ziemnego nie tylko bezpośrednio z Federacji Rosyjskiej, ale również z RFN. Widać to już dobrze w przypadku Ukrainy, która zaprzestała zakupów bezpośrednio z Rosji i zwiększyła wolumen importu z Niemiec. Oznacza to, że po uzyskaniu kontroli nad szlakami przesyłowymi gazu ziemnego Berlin może osłabiać pozycję Ukrainy i Słowacji oraz wpływać na wzrost uzależnienia tych państw od importu z Niemiec. Wskazują na to plany modernizacji i rozbudowy infrastruktury gazowej w tej części Europy, projektowane przez RFN w taki sposób, aby surowiec dostarczany za pomocą Nord Stream 2 dystrybuowany był dalej do Europy Środkowo-Wschodniej.

Gazociąg Nord Stream 2 może spowodować nasycenie Europy Środkowo-Wschodniej rosyjskim gazem ziemnym poprzez dostarczanie go z dwóch kierunków - bezpośrednio z Federacji Rosyjskiej oraz z RFN - a tym samym przyczynić się do osłabienia polityki dywersyfikacji źródel dostaw tego surowca do państw regionu. Byłoby to zatem sprzeczne z celami UE zapisanymi w Europejskiej strategii bezpieczeństwa energetycznego, gdzie w odniesieniu do gazu ziemnego określono 27 krótko- i średnioterminowych projektów strategicznych, mających poprawić bezpieczeństwo energetyczne poprzez zwiększenie możliwości dywersyfikacji źródeł dostaw ${ }^{17}$. $\mathrm{Na}$ liście widnieje terminal LNG w Świnoujściu, ale nie ma tam gazociągu Nord Stream 2. Projekt ten jest sprzeczny ze strategią UE, może bowiem obniżyć poziom bezpieczeństwa energetycznego państw Europy Środkowo-Wschodniej, a tym samym podważyć wiarygodność unijnej solidarności oraz sojuszów w ramach wspólnej polityki energetycznej. Zwiększenie zależności od Federacji Rosyjskiej poprzez niemiecki system przesyłu gazu ziemnego będzie prowadzić do monopolizacji unijnego rynku przez Gazprom, który już obecnie nadużywa swej dominującej pozycji.

Przejawia się to w blokowaniu przesyłu gazu ziemnego pomiędzy państwami, dyktowaniu części z nich zawyżonych stawek oraz wymuszaniu określonych zobowiązań politycznych $\mathrm{w}$ zamian za odpowiednią cenę. Niebędący członkiem UE aktor stosunków międzynarodowych ma więc bezpośredni wpływ na konkurencyjność poszczególnych unijnych gospodarek, gdyż poprzez odpowiednią politykę cenową może podwyższać lub obniżać

17 Komunikat Komisji do Parlamentu Europejskiego i Rady. Europejska strategia bezpieczeństwa energetycznego, SWD (2014) 330 final, Bruksela 2014, s. 11. 


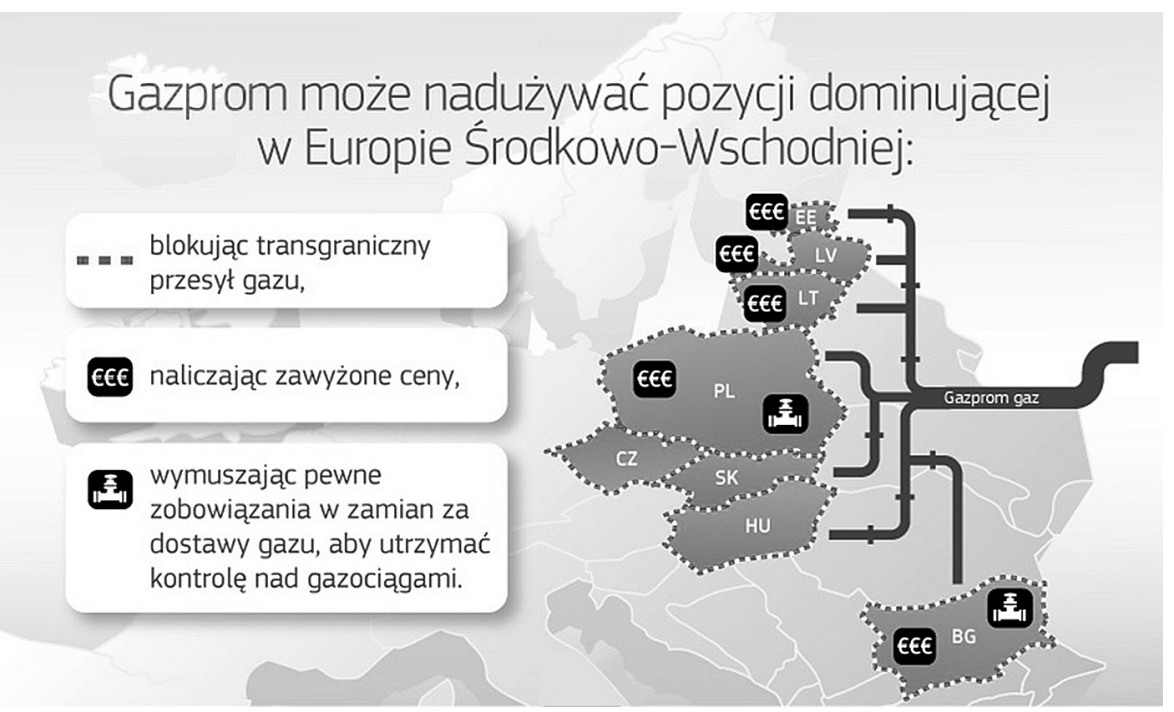

\section{Mapa 1. Obszar możliwości nadużywania przez Gazprom pozycji dominującej w Europie Środkowo-Wschodniej}

Źródło: Antitrust: Commission sends statement of objections to Gazprom-factsheet, „European Commission” [online], 22.04.2018 [dostęp: 10.10.2015], dostępny w internecie: $<$ http://europa.eu/rapid/press-release_MEMO-15-4829_en.htm>

koszty produkcji określonych towarów. Z uwagi na to, że założenia unijnej polityki energetyczno-klimatycznej faworyzują pewne paliwa (m.in. gaz ziemny), a ceny uprawnień do emisji dwutlenku węgla rosną w wyniku spekulacji, konkurencja pomiędzy państwami będzie się zaostrzać. Obszarem rywalizacji stanie się zdolność do tworzenia i utrzymania miejsc pracy w gospodarce, w której coraz większą rolę odgrywały będą automatyzacja i robotyzacja. Właśnie z tego względu tak ważne jest dążenie do budowy przewag konkurencyjnych, a tani dostęp do surowców energetycznych takie przewagi daje. Federacja Rosyjska będzie wykorzystywać tę sytuację do tworzenia podziałów w UE i zachęcać państwa członkowskie, by wchodziły z nią w sojusz przy określonych inicjatywach politycznych. Instrumentem wspierania tego procesu może być Nord Stream 2, a skala zjawiska zależała będzie od trzech czynników.

Pierwszy to rozbudowa przepustowości gazociągów przesyłowych wewnątrz Niemiec oraz połączeń międzysystemowych z państwami sąsiednimi. Opublikowana przez ENTSOG analiza planu rozwoju gazociągów Ten-year network development plan 2017 zawiera listę projektów z finalną decyzją inwestycyjną (ang. final investment decision - FID), na której znajduje 
się 31 pozycji, w tym 10 niemieckich z Nord Stream 2 na czele ${ }^{18}$. Łatwo zauważyć, że aż 9 niemieckich projektów nie widniało w wykazie projektów wspólnego zainteresowania UE (ang. PCI $2^{\text {nd }}$ list - project of common interest $)^{19}$. Dokładniejsza analiza ich realizacji pozwala stwierdzić, że mają umożliwiać optymalne wykorzystanie gazu odbieranego $\mathrm{z}$ istniejących oraz planowanych nitek Gazociągu Północnego dzięki zwiększeniu przepustowości punktów wejścia do systemu gazowego w Greifswaldzie ${ }^{20}$ oraz rozbudowie infrastruktury przesyłowej z północnej części kraju na południe, w kierunku Monachium, gdzie skoncentrowane jest wiele podziemnych magazynów gazu $^{21}$, oraz do Überackern, skąd poprzez niemiecko-austriacki interkonektor można transportować surowiec do hubu gazowego w Baumgarten. Oznacza to, że część nadwyżek gazu ziemnego może być eksportowana przez Austrię, która obecnie znaczącą ilość surowca z Federacji Rosyjskiej sprowadza gazociągami biegnącymi przez Ukrainę. Niemieckie plany inwestycyjne przewidują też rozbudowę tłoczni gazu ziemnego w Brandenburgii, a już obecnie realizowany jest gazociąg EUGAL, którym paliwo płynące z Nord Stream 2 może być przesyłane do Czech, a stamtąd do pozostałych państw Europy Środkowo-Wschodniej. Planowana jest również rozbudowa przepustowości interkonektora Waidhaus na granicy niemiecko-czeskiej, a niedaleko granicy z Polską mają powstać nowe stacje sprężania gazu ziemnego (Radeland 2 oraz Baruth/Mark). O skali redystrybucji będzie decydować przepustowość kolejnych połączeń międzysystemowych (interkonektorów) w Europie oraz cena gazu ziemnego. Im więcej rosyjskiego surowca będzie przesyłane w ten sposób, tym bardziej zmniejszać się będzie polityczna motywacja do projektowania alternatywnych tras dostaw, co przyczyni się do monopolizacji rynku i wzrostu pozycji politycznej RFN wobec państw regionu.

Drugim czynnikiem jest poziom zakontraktowania mocy przesyłowych interkonektorów gazowych przez poszczególne spółki energetyczne, które mogą zagwarantować sobie w ten sposób możliwości przesylu surowca. W UE znaczna liczba interkonektorów ma zarezerwowaną moc

18 Ten-year network development plan 2017, ENTSOG, Brussels 2017, s. 157.

19 Rozporzadzenie delegowane Komisji (UE) 2016/89 z dnia 18 listopada 2015 r. zmieniajace rozporzadzenie Parlamentu Europejskiego i Rady (UE) nr 347/2013 w odniesieniu do unijnej listy projektów będacych przedmiotem wspólnego zainteresowania, Dz. Urz. UE L19/1 z 27.01.2016.

20 Projekt inwestycyjny Extension Receiving Terminal Greifswald (TRA-F-768). Zob. Ten-Year Network..., s. 157.

21 Podziemne magazyny gazu ziemnego w Schmidthausen, Wolfsbergu, Inzenham-West, Bierwangu, Breitbrunnie/Eggstätcie. 
do 2035 r. (np. Waidhaus między Czechami a Niemcami i Badajoz między Hiszpanią a Portugalią) lub 2030 r. (Baumgarten między Słowacją a Austrią czy Bocholtz między Holandią a Niemcami) ${ }^{22}$. Do 2025 r. większość transgranicznych połączeń międzysystemowych zakontraktowana jest na poziomie $50-100 \%{ }^{23}$, co stoi w sprzeczności z logiką wspólnego rynku energii UE. Do grona podmiotów, które zakontraktowały przepustowość wielu połączeń transgranicznych na kilkadziesiąt lat, należą spółki energetyczne z Niemiec. Kontrolują więc przesył surowca na określonych punktach, a nawet mogą go blokować. Problem ten dostrzegła Komisja Europejska, wskazując na znaczne różnice w poziomie zakontraktowania i wykorzystania mocy w wielu miejscach. Już w 2012 r. zauważono, że niektóre całkowicie zarezerwowane połączenia wykorzystywane były na poziomie kilkudziesięciu procent ${ }^{24}$. Z raportu ACER wynika, że w 2017 r. wykorzystanie zakontraktowanej mocy przesyłowej transgranicznych połączeń międzysystemowych gazu ziemnego wyniosło średnio $57 \%{ }^{25}$. W związku z powyższym Komisja Europejska przyjęła kodeks sieci dotyczący mechanizmów alokacji zdolności w systemach przesyłowych gazu, który uregulował zasady podziału przepustowości na interkonektorach ${ }^{26}$. Przyczyniło się to do obniżenia liczby długoterminowych kontraktów z 93\% w 2015 r. do 84\% w 2017 r. Nadal jednak w przypadku większości transgranicznych transakcji gazowych mamy jeszcze do czynienia z zawartymi wcześniej długoletnimi umowami. Należy również zaznaczyć, że choć w UE obowiązuje zasada dostępu strony trzeciej do infrastruktury przesyłowej (ang. third party access - TPA), to jeden z nielicznych wyjątków odstąpienia od niej poczyniono na rzecz monopolu Gazpromu na łączącym Nord Stream z Czechami niemieckim gazociągu OPAL, pozwalając jednej z firm korzystać z 90\% jego przepustowości ${ }^{27}$. Podważa to wszystko wiarygodność RFN jako państwa dążącego do budowy konkurencyjnego rynku energii w UE.

22 ACER/CEER annual report on the results of monitoring the internal electricity and natural gas markets in 2012, ACER, CEER, Ljubljana-Brussels 2013.

23 Tamże.

24 Lanzot (Czechy-Słowacja) - 42\%, Julianadorp (Holandia-Wielka Brytania) - 43\%, IUK (Belgia-Wielka Brytania) - 23\%.

25 ACER market monitoring report 2017 - gas wholesale markets volume, ACER, CEER, Ljubljana-Brussels 2018, s. 5.

26 Rozporządzenie Komisji (UE) Nr 984/2013 z dnia 14 października 2013 r. ustanawiajace kodeks sieci dotyczący mechanizmów alokacji zdolności w systemach przesyłowych gazu i uzupetniajace rozporzadzenie Parlamentu Europejskiego i Rady (WE) nr 715/2009, Dz. Urz. UE L 273/5 z 15.10.2013.

27 Gazprom uzyskał dostęp do przepustowości na poziomie $90 \%$. 
Trzeci czynnik to cena gazu ziemnego w zawieranych kontraktach. To właśnie one budują pozycję polityczną Federacji Rosyjskiej w Europie. W obliczu rosnącej rywalizacji gospodarczej państw UE uzyskanie rabatu na gaz ziemny zwiększa konkurencyjność przemysłu, a z drugiej strony powoduje, że państwo kupujące surowiec najtaniej może go odsprzedawać innym. Analiza sytuacji na rynku gazu ziemnego w UE potwierdza funkcjonalność tego mechanizmu. Jeżeli do państw Europy Środkowo-Wschodniej surowiec dostarczany jest przez Gazprom po cenie wyższej niż do Niemiec, to naturalnie zwiększa się konkurencyjność niemieckiej gospodarki, a w szczególności tych sektorów, w których koszt wytworzenia produktów końcowych uzależniony jest od ceny gazu ziemnego (np. przemysłu chemicznego). Rosyjska polityka pośrednio przyczynia się w ten sposób do wspierania skuteczności niemieckiego eksportu. Różne ceny gazu (najniższe w przypadku Niemiec, a wyższe dla państw Europy Środkowo-Wschodniej) doprowadzą ponadto do sytuacji, gdy integracja rynku tego paliwa i rozszerzenie przepustowości interkonektorów umożliwią odsprzedawanie zgromadzonych nadwyżek surowca. Jeżeli zauważymy, że niemiecki system dysponuje największymi możliwościami przyjmowania gazu ziemnego w Europie (zob. tabela 1) oraz że Niemcy są głównym promotorem integracji

\section{Tabela 1. Przepustowość techniczna infrastruktury do importu gazu ziemnego do RFN}

\begin{tabular}{|c|c|c|}
\hline $\begin{array}{c}\text { Połączenia importowe } \\
\text { z danym państwem }\end{array}$ & $\begin{array}{c}\text { Przepustowość techniczna } \\
\text { (w GWh na dobę) }\end{array}$ & $\begin{array}{l}\text { Przepustowość techniczna } \\
\text { (w mld } \mathrm{m}^{3} \text { rocznie) }\end{array}$ \\
\hline $\begin{array}{l}\text { Federacja Rosyjska } \\
\text { (Greifswald) }\end{array}$ & 1742,0 & $65,08^{*}$ \\
\hline $\begin{array}{l}\text { Czechy } \\
\text { (gaz z Federacji Rosyjskiej) }\end{array}$ & 1104,4 & 41,26 \\
\hline $\begin{array}{l}\text { Polska } \\
\text { (gaz z Federacji Rosyjskiej) }\end{array}$ & 931,0 & 34,78 \\
\hline Holandia & 2248,7 & 84,01 \\
\hline Norwegia & 1711,3 & 63,94 \\
\hline Szwajcaria & 562,9 & 21,03 \\
\hline Austria & 401,0 & 14,98 \\
\hline Belgia & 313,1 & 11,70 \\
\hline Dania & 91,0 & 3,40 \\
\hline RAZEM & 9105,4 & $340,18 * *$ \\
\hline
\end{tabular}

Źródło: Obliczenia własne na podstawie Transmission capacity and system development maps, „ENTSOG” [online, dostęp: 10.01.2017], dostępny w internecie: <www.entsog.eu/maps/ transmission-capacity-map>. Użyto konwertera firmy Gasunie, który przelicza jednostki GWh na mld $\mathrm{m}^{3}$, uwzględniając średnie ciepło spalania na poziomie $35,17 \mathrm{MJ} / \mathrm{m}^{3}(\mathrm{GCV})$ 


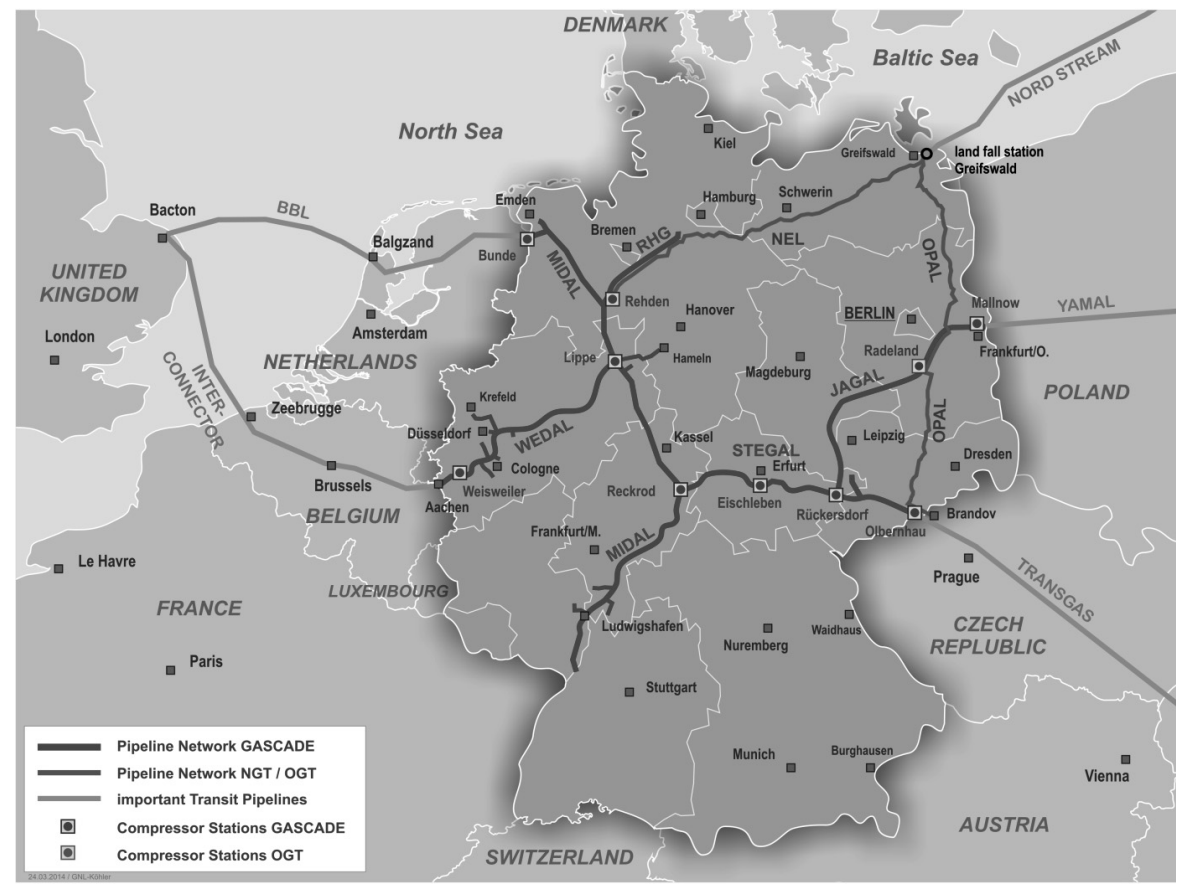

\section{Mapa 1. Niemiecka sieć gazociągów przesyłowych}

Źródło: Press photos, „Gascade” [online, dostęp: 25.07.2014], dostępne w internecie: $<$ http://www.gascade.de/en/presse/pressefotos/>

rynku energetycznego UE, to zrozumiemy funkcjonalność tych działań w szerszym kontekście. Skuteczność niemieckiej polityki warunkować będą niejawne kontrakty gazowe, w których niemieccy odbiorcy mogą uzyskać najniższą cenę. RFN jest więc przeciwnikiem jawności kontraktów gazowych w UE czy chociażby zwiększenia transparentności w tym zakresie.

\section{Nord Stream 2 jako element koncepcji „centrum-peryferie”}

Skuteczność niemieckiej polityki energetycznej zależy od współpracy politycznej z importerami surowców, gdyż umożliwiają oni dywersyfikację źródeł i kierunków dostaw gazu ziemnego, firm dostarczających, a także struktury kontraktowej. Dla Niemiec ważne są więc nie tylko relacje polityczne z Federacją Rosyjską, ale również z Norwegią ${ }^{28}$, Holandią i Danią ${ }^{29}$.

28 M. Ruszel, Polityczne i ekonomiczne znaczenie integracji energetycznej pomiędzy Norwegia a Niemcami, „Bezpieczeństwo. Teoria i Praktyka” 2016, nr 1 (22), s. 67-78.

29 Tenże, The political importance of energy cooperation between Germany and Denmark on the European Union energy market, „E3S Web of Conferences” 2016, vol. 10. 
Największym wyzwaniem politycznym dla Niemiec staje się współzależność z Federacją Rosyjską. Niektóre państwa Europy Środkowo-Wschodniej dążą do zdywersyfikowania źródeł dostaw gazu ziemnego i zmniejszenia zależności od Rosji. W Niemczech państwo to postrzega się natomiast jako partnera, którego można włączyć do współpracy z UE, dlatego też projekt Nord Stream 2 wbrew założeniom unijnej strategii bezpieczeństwa energetycznego jest w kontrze do tych celów. Analiza sytuacji rynkowej wskazuje, że Unia nie potrzebuje dzisiaj nowego bezpośredniego gazociągu z Federacji Rosyjskiej do RFN, tym bardziej że rosyjski i azjatycki gaz ziemny przesyłany jest do państw unijnych gazociągami:

- Braterstwo (ang. Brotherhood) - przez Ukrainę i Słowację, o przepustowości ok. $100 \mathrm{mld} \mathrm{m}^{3}$;

- Jamał-Europa - przez Białoruś i Polskę, o przepustowości ok. 33 mld m³;

- Nord Stream - bezpośrednie połączenie z Rosji do RFN o przepustowości na poziomie $55 \mathrm{mld} \mathrm{m}^{330}$.

Gazociągi Braterstwo i Jamał-Europa zapewniają niektórym państwom Europy Środkowo-Wschodniej pozycję pośrednika tranzytowego, co zmniejsza ryzyko całkowitego wstrzymania rosyjskich dostaw surowca $z$ jednoczesnym wypełnianiem zobowiązań kontraktowych wobec Europy Zachodniej, a zatem podnosi bezpieczeństwo energetyczne krajów regionu. $Z$ ekonomicznego punktu widzenia najbardziej zasadne jest wykorzystanie pełnej mocy istniejącej infrastruktury. Rosja nie jest jednak państwem, w którym decyzje polityczne podporządkowane są ekonomii - jej priorytetem jest osiąganie strategicznych celów geopolitycznych, a jeden z nich to wpływanie na politykę w krajach Europy Środkowo-Wschodniej. Realizacja tego celu we współpracy z RFN (np. budowa gazociągu Nord Stream 2) podważa wiarygodność unijnej solidarności energetycznej, a jednocześnie daje Niemcom długoterminową korzyść - budowę centrum dystrybucji gazu ziemnego dla państw UE. Z perspektywy teoretycznej widoczne jest tu zastosowanie modelu rozwoju zależnego, tzw. centrum-peryferie ${ }^{31}$. Centrum dąży do uzyskania takiej ceny gazu, która będzie faworyzowała państwa przemysłowe oraz uzależniała od nich peryferie. Rolę centrum pełniłby hub gazowy w Niemczech, a peryferiami - wskutek spełnienia wyżej opisanych czynników oraz zbudo-

30 Ten-year network..., s. 108.

31 R. Prebisch, Commercial policy in the underdeveloped countries, „American Sociological Review" 1959, t. 49 (2), s. 251-273. 
wania wspólnego rynku energii - stałyby się państwa zwiększające import gazu ziemnego z RFN. Byłaby to jednak dla nich tylko pozorna, kierunkowa dywersyfikacja, gdyż surowiec nadal pochodziłby z Federacji Rosyjskiej. Jeżeli zauważymy, że przepustowość wszystkich punktów wejścia do niemieckiego systemu przesyłowego wynosi obecnie ponad $300 \mathrm{mld} \mathrm{m}^{3}$, a planowane nowe nitki Gazociągu Północnego zwiększą ją jeszcze o $55 \mathrm{mld} \mathrm{m}^{3}$, to dojdziemy do wniosku, że strategicznym celem długoterminowym RFN jest budowa centrum dystrybucji gazu ziemnego dla UE. $Z$ tej perspektywy projekt Nord Stream 2 logicznie wpisuje się w działania na rzecz jednoczesnego zmniejszenia roli tranzytowej Ukrainy oraz osłabienia możliwości dywersyfikacji źródeł dostaw tego paliwa do Europy Środkowo-Wschodniej. Istotne znaczenie ma więc zaangażowanie polityczne USA oraz budowa przez nie kolejnych terminali do eksportu LNG, pozwalających na realizowanie dostaw do Europy. Może to doprowadzić do rywalizacji o odbiorcę końcowego pomiędzy rosyjskim a amerykańskim gazem. Co prawda Niemcy zapowiedziały ostatnio budowę terminala LNG, ale kluczowe znaczenie mają dla nich inwestycje, które umożliwią tranzyt rosyjskiego surowca $\mathrm{z}$ Nord Stream 2 nawet do hubu gazowego w austriackim Baumgarten. Co istotne, cele RFN sprzęgają się z rosyjskimi planami zmonopolizowania rynków Europy Środkowo-Wschodniej: Niemcy potrzebują rosyjskiego gazu, a Rosja - dostępu do niemieckiej infrastruktury energetycznej. Tworzy się zatem kolejna współzależność pomiędzy tymi państwami. Warto również przypomnieć, że rynek rosyjski jest jednym z wielu kierunków eksportu niemieckich towarów. Odpowiednio projektowana współpraca obu państw w sektorze gazowym da niemieckiej gospodarce trwałe zdolności budowania przewag konkurencyjnych względem pozostałych państw unijnych. Sam gazociąg Nord Stream 2 mógłby stać się elementem zwiększenia płynności niemieckiego rynku gazowego, co jest szczególnie istotne w kontekście zmniejszającego się wydobycia gazu ziemnego w Holandii, która niebawem przestanie być jego eksporterem do państw UE. Rosyjski surowiec przesyłany za pomocą Nord Stream 2 mógłby zatem wyrównać niedobory na rynku. W opinii Alana Rileya nowe nitki Gazociągu Północnego przyczynią się również do obniżenia cen gazu na niemieckim rynku ${ }^{32}$.

32 A. Riley, Nordstream 2: how Germany lets down Europe, „The Globalist” [online], 28.02.2018 [dostęp: 15.03.2018], dostępny w internecie: <https://www.theglobalist.com/ germany-nordstream2-energy-security-european-union/>. 


\section{Podsumowanie}

Politykę energetyczną Republiki Federalnej Niemiec współkształtują czynniki wewnętrzne i zewnętrzne, przy czym kluczową rolę odgrywają te pierwsze. Niemieckie ośrodki biznesowe, zorientowane na eksport swoich towarów i usług, dążą do zachowania odpowiednich sojuszów energetycznych oraz tworzenia warunków zwiększających przewagę konkurencyjną państwa na wspólnym unijnym rynku energetycznym. Niemcy współuczestniczą więc w realizacji politycznego projektu Nord Stream 2, aby wzmocnić swoją pozycję poprzez bezpośrednią kontrolę szlaków przesyłowych gazu ziemnego z Federacji Rosyjskiej. $\mathrm{Z}$ ich perspektywy będzie to wzmocnienie bezpieczeństwa dostaw surowca kosztem ograniczenia roli Ukrainy i Słowacji jako państw tranzytowych. Obydwa te kraje staną się w rezultacie bardziej podatne na presję polityczną Federacji Rosyjskiej i zwiększą swoją zależność od niemieckich dostaw. Nord Stream 2 przyczyni się do nasycenia rosyjskim gazem Europy Środkowo-Wschodniej i osłabi wolę realizacji unijnych projektów dywersyfikacyjnych. Już obecnie architektura infrastruktury przesyłowej przyczynia się do uzależnienia państw tego regionu od surowca z Rosji lub Europy Zachodniej, dostarczanego przez RFN. Budując nowy gazociąg, Niemcy będą realizować cele strategiczne kosztem zaufania politycznego partnerów, gdyż promują projekt będący w kontrze do unijnej strategii bezpieczeństwa energetycznego i przyczyniają się do monopolizacji rynku wbrew założeniom konkurencyjności. Czy Komisja Europejska zachowa wiarygodność, godząc się na podporządkowanie unijnej polityki energetycznej relacjom niemiecko-rosyjskim? Czy przepisy antymonopolowe mają służyć wszystkim państwom unijnym, czy tylko wybranym? Czy prawo konkurencji na rynku energetycznym ma być egzekwowane wszędzie? Podstawą budowy wspólnego rynku energii UE miało być egzekwowanie unijnego prawa.

Projekt Nord Stream 2 przyczyni się do budowy centrum dystrybucji rosyjskiego gazu ziemnego w RFN, która dzięki dobremu partnerstwu z Federacją Rosyjską kupuje surowiec taniej niż inne państwa regionu. Realizację tego celu ułatwi dalsza rozbudowa niemieckiej infrastruktury energetycznej oraz połączeń międzysystemowych. Niemcy osiągną zatem na rynku najważniejszą pozycję, zgodnie z koncepcją ,centrum-peryferie”. Powyższe wnioski pozwalają na pozytywną weryfikację dwóch hipotez badawczych: że współpraca energetyczna pomiędzy RFN i Rosją wzmacnia niemiecką pozycję polityczną w Europie Środkowo-Wschodniej, a podstawą budowy tej pozycji jest 
rozwinięta infrastruktura energetyczna. Trzecia hipoteza zakładała, że budowie centrum dystrybucji gazu ziemnego w Niemczech sprzyjać będzie osłabienie pozycji tranzytowej Ukrainy oraz Słowacji. I ona może zostać zweryfikowana pozytywnie, pod warunkiem że powstanie Nord Stream 2. Tym samym autor pozytywnie zweryfikował zasadniczą tezę artykułu, zakładającą przyczynienie się budowy gazociągu Nord Stream 2 do stworzenia niemieckiego centrum dystrybucji gazu ziemnego dla Europy Środkowo-Wschodniej. Jeżeli Unia Europejska chce zachować wiarygodność, powinna doprowadzić do wymuszenia pełnej konkurencyjności tego projektu. W przeciwnym razie Nord Stream 2 przyczyni się do osłabienia zaufania politycznego między państwami członkowskimi i dalszych podziałów, wbrew logice solidarności energetycznej i budowie wspólnego rynku energii.

\section{Bibliografia}

ACER/CEER annual report on the results of monitoring the internal electricity and natural gas markets in 2012, ACER, CEER, Ljubljana-Brussels 2013.

ACER market monitoring report 2017 - gas wholesale markets volume, ACER, CEER, Ljubljana-Brussels 2018.

Antitrust: Commission sends statement of objections to Gazprom - factsheet, „European Commission" [online], 22.04.2018 [dostęp: 10.10.2015], dostępny w internecie: <http:// europa.eu/rapid/press-release_MEMO-15-4829_en.htm>.

Cziomer E., Polityka zagraniczna Niemiec $w$ dobie wyzwań globalizacji, bezpieczeństwa międzynarodowego oraz integracji europejskiej po 2005 roku, Dom Wydawniczy ELIPSA, Warszawa-Kraków 2010.

Energiewende im Überblick, „Die Bundesregierung” [online, dostęp: 4.07.2017], dostępny w internecie: <https://www.bundesregierung.de/breg-de/themen/energiewende/energiewende-im-ueberblick-229564>.

Germany as civilian power? The foreign policy of the Berlin Republic, ed. S. Harnisch, H. Maull, Manchester University Press, Manchester-New York 2001.

Illing F., Energiepolitik in Deutschland. Die energiepolitischen Maßnahmen der Bundesregierung 1949-2015, Nomos, Baden-Baden 2016.

Importabhängigkeit und Selbstversorgungsgrad Deutschlands bei einzelnen Primärenergierohstoffen in den Jahren 2006 und 2016, „BGR” [online, dostęp: 24.11.2018], dostępny w internecie: <https://www.bgr.bund.de/DE/Themen/Energie/Bilder/Energiestudie2017/ene_importabhaenigkeit_2016_g.html?nn=1542226>.

Klare M., Resource wars. The new landscape of global conflict, Metropolitan Books, New York 2001.

Komunikat Komisji do Parlamentu Europejskiego i Rady. Europejska strategia bezpieczeństwa energetycznego, SWD (2014) 330 final, Bruksela 2014.

Kundnani H., Germany as a geo-economic power, „The Washington Quarterly” 2011, vol. 34, issue 3.

Leksykon politologii, red. A. Antoszewski, R. Herbut, Atla 2, Wrocław 2000. 
Molo B., Polityka bezpieczeństwa energetycznego Niemiec w XXI wieku, Oficyna Wydawnicza Krakowskiej Akademii im. Frycza Modrzewskiego, Kraków 2013.

Prebisch R., Commercial policy in the underdeveloped countries, „American Sociological Review" 1959, t. 49 (2).

Press photos, „Gascade” [online, dostęp: 25.07.2014], dostępne w internecie: $<$ http://www.gascade.de/en/presse/pressefotos/>.

Riley A., Nordstream 2: how Germany lets down Europe, „The Globalist” [online], 28.02.2018 [dostęp: 15.03.2018], dostępny w internecie: <https://www.theglobalist.com/ germany-nordstream2-energy-security-european-union/>.

Rozporzadzenie delegowane Komisji (UE) 2016/89 z dnia 18 listopada 2015 r. zmieniajace rozporzadzenie Parlamentu Europejskiego i Rady (UE) nr 347/2013 w odniesieniu do unijnej listy projektów będących przedmiotem wspólnego zainteresowania, Dz. Urz. UE L19/1 z 27.01.2016.

Rozporządzenie Komisji (UE) Nr 984/2013 z dnia 14 października 2013 r. ustanawiające kodeks sieci dotyczacy mechanizmów alokacji zdolności w systemach przesyłowych gazu i uzupetniajace rozporzadzenie Parlamentu Europejskiego i Rady (WE) nr 715/2009, Dz. Urz. UE L 273/5 z 15.10.2013.

Ruszel M., The political importance of energy cooperation between Germany and Denmark on the European Union energy market, „E3S Web of Conferences” 2016, vol. 10.

Ruszel M., Polityczne i ekonomiczne znaczenie integracji energetycznej pomiędzy Norwegia a Niemcami, „Bezpieczeństwo. Teoria i Praktyka” 2016, nr 1 (22).

Ruszel M., Strategia polityki energetycznej Republiki Federalnej Niemiec, „Sprawy Międzynarodowe" 2017, t. 70, nr 2.

Ruszel M., Strategic goals of energy security policy of the Federal Republic of Germany, „Politeja” 2015, nr 5 (50).

Schwerpunkte deutscher Außenpolitik, „Deutsche Vertretungen in der Türkei” [online, dostęp: 20.01.2017], dostępny w internecie: <https://tuerkei.diplo.de/tr-de/themen/politik/-/ $1670126>$.

Szabo S.F., Germany, Russia and the rise of geo-economics, Bloomsbury Publishing, LondonNew Dehli-New York-Sydney 2014.

Ten-year network development plan 2017, ENTSOG, Brussels 2017.

Traktat o funkcjonowaniu Unii Europejskiej, Dz. Urz. UE C 326/47.

Transmission capacity and system development maps, „ENTSOG” [online, dostęp: 10.01.2017], dostępny w internecie: <www.entsog.eu/maps/transmission-capacity-map>.

Ulatowski R., Analiza porównawcza polityki energetycznej importerów i eksporterów surowców energetycznych na przyktadzie Niemiec i Arabii Saudyjskiej. Perspektywa geoekonomiczna, Wydawnictwo Naukowe Scholar, Warszawa 2016. 